\title{
An Evaluation of a Proposed Ventilation System for Melbourne's $\mathrm{CH}_{2}$ Building
}

Lu Aye and Robert James Fuller (University of Melbourne)

\section{ABSTRACT}

The understanding of ventilation requirements in commercial buildings has been significantly revised in the last $10-15$ years. A link between health, productivity and increased fresh air use has been established by some research and this understanding underpins the ventilation philosophy adopted for the $\mathrm{CH}_{2}$ building The ventilation system design for $\mathrm{CH}_{2}$ that has been evaluated in this paper envisages a mechanically driven system during the day, using the displacement technique to distribute filtered air. All introduced air will be drawn from outside and no recycling of air will occur. Natural ventilation will be employed at night using the stack effect, enhanced by turbine ventilators. This paper critiques the proposed ventilation system in the light of international experience and the particular conditions of the building's location. The evidence suggests that natural ventilation sometimes may be inadequate to achieve the desired objectives. Minimization of indoor pollutants, adequate filtration and high levels of ventilation should, however, ensure satisfactory air quality during occupied hours.

Keywords: office buildings, indoor air quality, ventilation, productivity.

\section{INTRODUCTION}

A study of 56 European office buildings found that their air quality was poor and that there was substantial dissatisfaction among the occupants (Bluyssen et al., 1996). These buildings were fitted with conventional HVAC systems. The study substantiates the view that modern office buildings with HVAC systems do not necessarily provide healthy working environments, despite the use of energy-intensive conditioning equipment and sophisticated control systems. $\mathrm{CH}_{2}$, currently under construction in Melbourne Australia, is hoping demonstrate that it is possible to achieve a high quality office environment simultaneously with much reduced energy consumption. The overall design vision is to "set a new international standard in ecologically sustainable design" (CoM, 2004) and the Green Building Council of Australia has already given the proposed design a six Green Star rating.

The ventilation concept proposed for the $\mathrm{CH}_{2}$ building is in sharp contrast to the conventional approach. This difference is driven by a design philosophy based on two considerations. Firstly, the energy used by a conventional ventilation system requires electricity, which is a greenhouse intensive energy source in Victoria. Instead the $\mathrm{CH}_{2}$ building aims to demonstrate how natural forces can be used to adequately drive the fresh air through the building. The result should be a substantial reduction in energy requirements. The other motivation for the departure from conventional ventilation thinking is the belief that fresh air in buildings is vital for occupant health and productivity. By increasing the level of fresh air intake substantially, it is believed that these two indicators will be improved.

The aim of this paper is to assess the proposed $\mathrm{CH}_{2}$ ventilation design and likely air quality in the light of international precedents and best practice. Since the office is still under construction, no measured data from the building is available to verify performance and the main source of information has been $\mathrm{CH}_{2}$ design consultants' reports. Therefore the proposed design has largely been evaluated using a selection of the design consultants' documentation and refereed literature in international journals. Design changes made subsequent to this evaluation are obviously not considered. Some assessment of the effectiveness of particular aspects of the proposed design has also been attempted using local data.

In assessing the ventilation system and likely internal air quality, this paper addresses a number of questions. What is the nature and magnitude of the hazards that can be found in a typical office building? What is the quality of the outside air being introduced into the $\mathrm{CH}_{2}$ building? How well are the individual components likely to perform? What is the evidence that improved health and productivity will result from this approach? And finally, what has been the experience of users of similar buildings? This study begins with a brief summary of the potential hazards that may need to be addressed in the $\mathrm{CH}_{2}$ building. Since large quantities of outside air are to be introduced into the building, the quality of the air in Melbourne's central business district is then discussed. The overall objectives and operation of the $\mathrm{CH}_{2}$ ventilation system are then described, followed by a review of the individual components and their expected performance. Finally, the performance of other buildings is reported, particularly with respect to the influence of their ventilation system on air quality, and the health and productivity of their occupants.

\section{INDOOR AIR AND OCCUPANT HEALTH}

It is likely that if occupants were as knowledgeable about the quality of the air they breathe within their buildings as they are about the food they eat, then much greater action would be demanded to improve the indoor environment. A healthy indoor environment can be defined in terms of safe levels of chemical, biological, physical and ergonomic hazards. Some of the physical and ergonomic hazards (e.g. noise and illumination) are not relevant to an assessment of air quality and the ventilation system. Table 1 indicates the possible diseases and their chemical or biological causes, related to air quality, which may be encountered in buildings. 


\begin{tabular}{|l|l|}
\hline \multicolumn{1}{|c|}{ Disease } & \multicolumn{1}{c|}{ Cause } \\
\hline Rhinitis sinusitis & Molds, laser toner, carbonless copy paper, cleaning agents \\
\hline Asthma & Molds, laser toner, carbonless copy paper, cleaning agents \\
\hline Hypersensitivity pneumonitis & Molds, moisture \\
\hline Organic dust toxic syndrome & Gram-negative bacteria \\
\hline Contact dermatitis & Molds, laser toner, carbonless copy paper \\
\hline Contact urticaria & Office products, carbonless copy paper \\
\hline Eye irritation & Low relative humidity, volatile organic compounds, particulates \\
\hline Nasal irritation & Low relative humidity, volatile organic compounds, particulates \\
\hline Central nervous system symptoms & Volatile organic compounds, carbon monoxide, cytokines from bioaerosol exposure \\
\hline Legionnaires disease & $\begin{array}{l}\text { Aerosols from contaminated water sources, shower heads, water faucet aerators, } \\
\text { humidifiers, potable water sources (hot water heaters) }\end{array}$ \\
\hline
\end{tabular}

(extracted from Table 1, ASHRAE, 2001, Chapter 9-Indoor Environmental Health)

Table 1: Diseases and their causes related to buildings

In order to protect the health of building occupants, standards are in place to ensure acceptable levels of contaminants (gaseous and particulate) known to be harmful to human health. Many countries and organizations have established such guidelines. For example, the World Health Organization has published guidelines for Europe for some gaseous contaminants, and some of those considered relevant to this study are shown in Table 2.

\begin{tabular}{|c|c|c|c|}
\hline \multirow{2}{*}{ Pollutant } & \multicolumn{2}{|c|}{ Time-weighted average } & \multirow{2}{*}{$\begin{array}{l}\text { Averaging } \\
\text { time }\end{array}$} \\
\hline & $\mathrm{mg} / \mathrm{m}^{3}$ & ppm & \\
\hline \multirow[t]{2}{*}{ Carbon monoxide } & 10 & 8.7 & $8 \mathrm{~h}$ \\
\hline & 30 & 25.0 & $1 \mathrm{~h}$ \\
\hline \multirow[t]{2}{*}{ Nitrogen dioxide } & 0.04 & 0.02 & annual \\
\hline & 0.20 & 0.11 & $1 \mathrm{~h}$ \\
\hline \multirow[t]{2}{*}{ Ozone } & 0.12 & 0.06 & $8 \mathrm{~h}$ \\
\hline & 0.20 & 0.10 & $1 \mathrm{~h}$ \\
\hline Formaldehyde & 0.10 & 0.081 & $30 \mathrm{~min}$ \\
\hline Benzene $^{a}$ & \multicolumn{2}{|c|}{ No save level } & - \\
\hline
\end{tabular}

a - from WHO, 2000, Chapter 5.2 Benzene

(from Table 4, Chapter 9, ASHRAE, 2001, - except where noted)

Table 2: Selected gaseous contaminants and WHO recommended safe levels

Particulate contaminates can come from natural or anthropogenic sources. The former includes wind blown dust and smoke from forest fires, both of which on occasions can visibly influence Melbourne's air quality. Particles from anthropogenic sources are those generated by human activities including fuel combustion (e.g. motor vehicles and wood burning stoves) and industrial processes. Since the $\mathrm{CH}_{2}$ building is located in a city centre, motor vehicle particulates are of particular interest. Air pollution from wood burning stoves is also of concern in winter in Melbourne, when its contribution to particulate emissions can be twice that of motor vehicles.
Particulates are classified into two sizes, PM10 and PM2.5, being the particle sizes that can enter the lung airways and penetrate the lung lining respectively. Some particle size diameters of interest to this study are shown in Table 3. The large range of particle sizes from both internal and external sources illustrates the challenge for filtering systems in buildings. In terms of exposure levels, various recommendations exist. In Australia, the recommended exposure standard for non-toxic inspirable dust in general should be $10 \mathrm{mg}$ $\mathrm{m}^{-3}$ (NOHSC, 1995a). 


\begin{tabular}{|l|c|}
\hline \multicolumn{1}{|c|}{ Particle description } & Particle diameter $(\mu \mathrm{m})$ \\
\hline Dust mites & $100-300$ \\
\hline Pollen & $10-100$ \\
\hline Spores & $3.0-35$ \\
\hline Vehicle emissions & $1.0-150$ \\
\hline Copier toner & $0.4-3.0$ \\
\hline Bacteria & $0.3-30$ \\
\hline Burning wood & $0.2-3.0$ \\
\hline Air freshener & $0.2-2.0$ \\
\hline Clay & $0.1-40$ \\
\hline Paint pigments & $0.1-5.0$ \\
\hline Viruses & $0.01-0.05$ \\
\hline
\end{tabular}

(from Owen et al., 1992, cited in ASHRAE, 2001)

Table 3: Sizes of selected particulates

Carbon dioxide, while not a pollutant, can be harmful at high levels ( $>35000 \mathrm{ppm}$ ) due to oxygen displacement. At lower levels, it is also used as an indicator of indoor air quality. The European standard organisation, $\mathrm{CEN}$, has established levels of $\mathrm{CO}_{2}$ above the outside level, with an associated qualitative description of the air quality (Table 4).

\begin{tabular}{|l|c|}
\hline \multicolumn{1}{|c|}{ Description } & $\begin{array}{c}\mathrm{CO}_{2} \text { above the outside level } \\
(\mathrm{ppm})\end{array}$ \\
\hline High indoor air quality & $<$ or $=400$ \\
\hline Medium indoor air quality & $400-600$ \\
\hline Acceptable indoor air quality & $600-1000$ \\
\hline Low indoor air quality & $>1000$ \\
\hline
\end{tabular}

(source: Olesen, 2004)

Table 4: Levels of $\mathrm{CO}_{2}$ and associated air quality level 


\section{MELBOURNE AIR QUALITY}

A study has shown that the daily mortality from ambient air pollution in Melbourne is increasing (EPA, 2000). The strongest relationships between various pollutants and this increase were for ozone and nitrogen dioxide. A primary source of this pollution is the emissions from motor vehicles. Since the $\mathrm{CH}_{2}$ building is located in the heart of the city and will be drawing large quantities of outside air into the building, the quality of that air is crucial to the health and well-being of the $\mathrm{CH}_{2}$ occupants. The closest EPA outdoor air quality monitoring station to the $\mathrm{CH}_{2}$ building is located approximately 750 metres away on the roof of an inner city university building. The air sampling height is 19 metres above ground level. The normal sampling height is six metres, but there are apparently no vertical gradients at the RMIT site (EPA, 2001).
An indication of inner city Melbourne's air quality may be obtained from the EPA's annual air monitoring tables (EPA, 2004a). Table 5 shows the maximum levels of the four pollutants cited in the EPA's mortality study and measured at the RMIT site in 2003. Also shown in the table is the EPA's policy objective. While maximum measured levels of ozone, carbon monoxide and nitrogen dioxide met the EPA's outdoor air quality policy objective, PM10 particulate levels exceeded that level. PM10 particles are of major concern because they penetrate the respiratory system, with the finer particles (PM2.5) penetrating more deeply into the lungs. These include dust, soot, pollen, asbestos and many other chemicals. Exposure to particles increases the risk of death from heart and lung disease. Particles can carry carcinogenic materials to the lungs. They can also exacerbate asthma and other chronic lung conditions.

\begin{tabular}{|l|c|c|c|c|c|}
\hline \multicolumn{1}{|c|}{ Pollutant } & Units & $\begin{array}{c}\text { Averaging } \\
\text { Period }\end{array}$ & $\begin{array}{c}\text { Maximum } \\
\text { Measured } \\
\text { Level }\end{array}$ & $\begin{array}{c}\text { EPA } \\
\text { Objective }\end{array}$ & $\begin{array}{c}\text { WHO } \\
\text { Guideline } \\
\text { Values }\end{array}$ \\
\hline Ozone & $\mathrm{ppm}$ & 1 hour & 0.093 & 0.10 & $0.06(8 \mathrm{hrs})$ \\
\hline Carbon Monoxide & $\mathrm{ppm}$ & 8 hours & 3.9 & 9.0 & 8.73 \\
\hline Nitrogen Dioxide & $\mathrm{ppm}$ & 1 hour & 0.069 & 0.12 & 0.114 \\
\hline Particulates $\left(\mathrm{PM}_{10}\right)$ & $\mu \mathrm{g} / \mathrm{m}^{-3}$ & 1 day & 279.4 & 50 & $*$ \\
\hline $\mathrm{PM}_{2.5}$ & $\mu \mathrm{g} / \mathrm{m}^{-3}$ & 1 day & n.a. & 25 & $*$ \\
\hline
\end{tabular}

* No recommended guideline values, n.a. indicates 'not available'

Table 5: Maximum levels of four ambient air pollutants measured at RMIT site in 2003

Future air quality goals have also been set for Melbourne in terms of the number of days when pollution levels exceed certain allowances. In 2003, the ozone and particulate goals for 2008 were not met. The bush fires and dust storms during this period have been cited for these excesses (EPA, 2004b). Whatever the cause - and these are both naturally occurring events - the incoming air into the $\mathrm{CH}_{2}$ building may be in excess of EPA objectives. In addition, both the $\mathrm{CH}_{2}$ and the monitoring station are in close proximity to the main road through the heart of Melbourne. The access of private vehicles to this road has been relaxed in recent times, following a period of restrictions, and it is possible that traffic and therefore emissions in the city centre will increase if traffic levels return to their pre-restricted levels. Motor vehicles currently account for $16 \%$ of $\mathrm{PM}_{10}$ airborne particles.

\section{THE $\mathrm{CH}_{2}$ VENTILATION SYSTEM}

\section{System objectives}

The main design objective of the $\mathrm{CH}_{2}$ ventilation system is to avoid recycling any air into the offices. The air entering the offices is to be both $100 \%$ fresh and filtered. In addition, the quantity of introduced fresh air will be substantially higher than required by the Australian Standard. Another goal of the system is to avoid the mixing of fresh and stale air within the occupied spaces.

\section{System overview}

The $\mathrm{CH}_{2}$ ventilation system can be characterized as 'mechanically driven' during the day and 'naturally driven' at night - i.e. ventilation is achieved by wind, stack and buoyancy effects. During the day, fresh air is drawn from the roof level (i.e. from approximately 38 metres above street level and travels down ducts located on the south side of the building). Some conditioning of the ventilation air takes places prior to its delivery to the offices. The displacement system supply temperature is to be $20^{\circ} \mathrm{C}$ and depending on the outside air temperature, the ventilation air will be heated or cooled to this temperature by heat exchangers. The air will then be passed through filters prior to its entry into the offices at a low velocity $\left(1.5 \mathrm{~m} \mathrm{~s}^{-1} \mathrm{~m}^{-2}\right)$ through controllable vents in the floors. The minimum fresh air requirement has been set at $22.5 \mathrm{I} \mathrm{s}^{-1} \mathrm{~m}^{-2}$ to suit an occupancy level of one person for every $15 \mathrm{~m}^{2}$. Assuming a mean office height of $2.9 \mathrm{~m}$, there will be 1.9 air changes per hour $\left(\mathrm{ACH}^{-1}\right)$. Natural convection forces are used to move the air upward through the office spaces to vents in the ceiling. The stale air will be exhausted through ducts located on the north side of the building. Wind turbines are assumed to assist the exhaust process. Figure 1 shows the movement of air at office level schematically. 


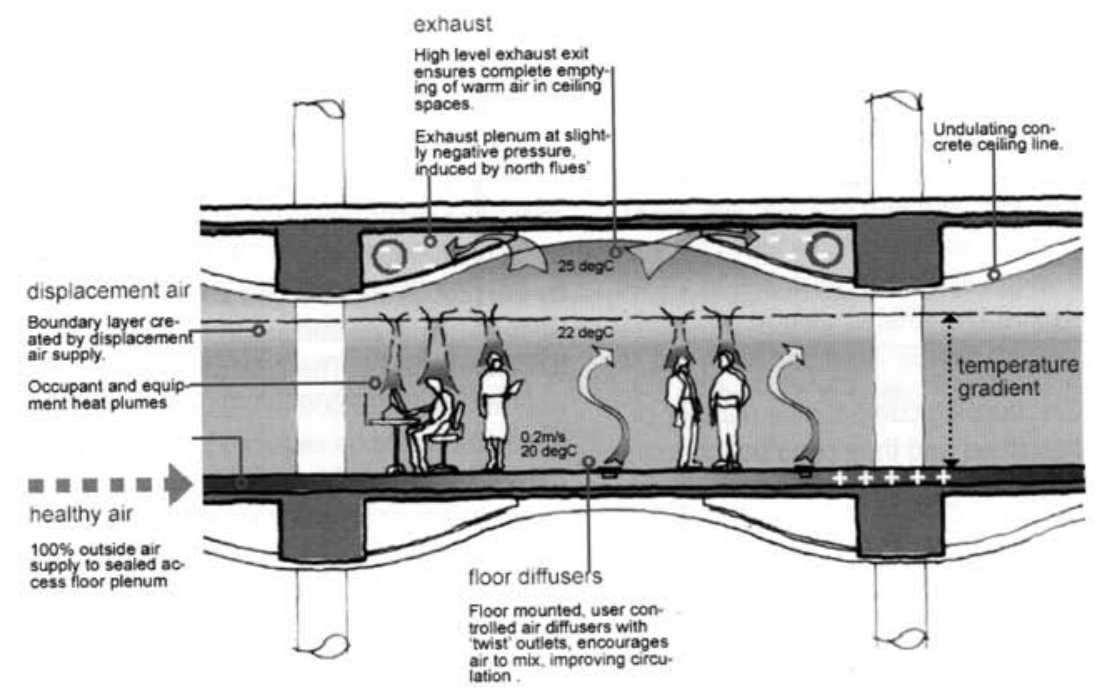

AIR FLOW - OFFICES

(source: CoM, 2004)

Figure 1: Schematic overview of ventilation system in $\mathrm{CH}_{2}$ building

Some parts of the $\mathrm{CH}_{2}$ building, such as the toilets, rely on direct natural ventilation through windows (Figure 2). It is not clear, however, how a continuous flow of fresh air can be achieved because only louvres at an upper level are indicated and no lowlevel openings are shown.

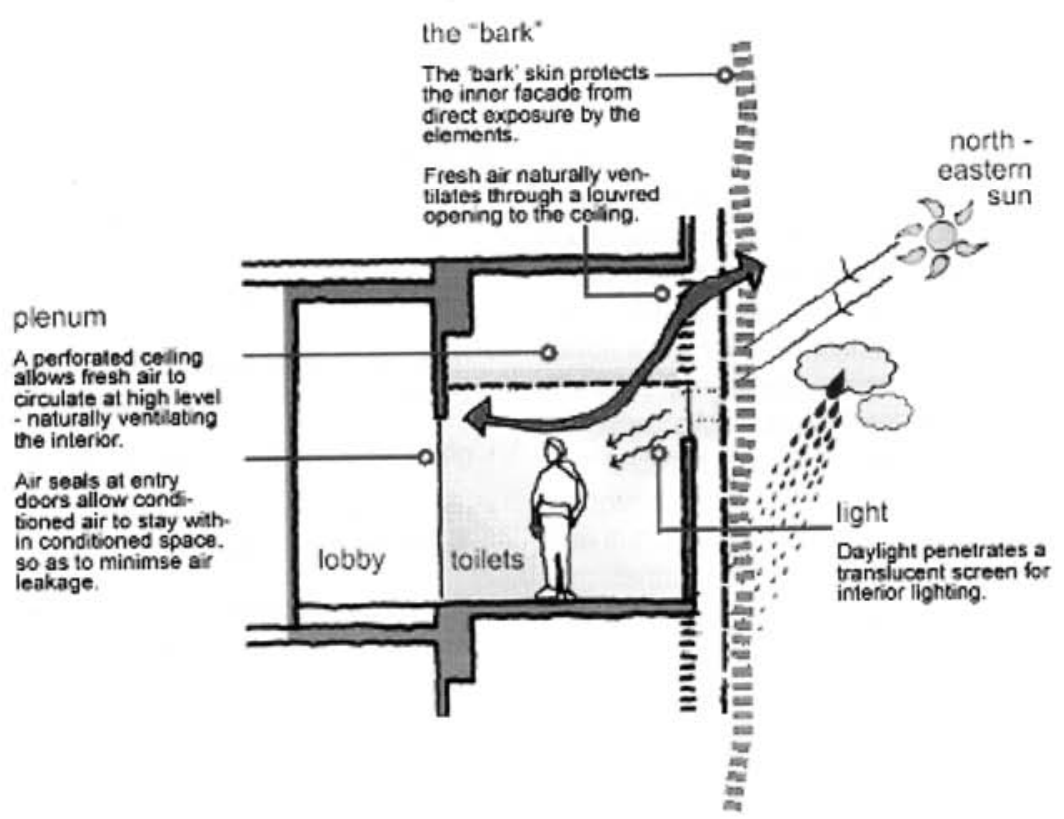

AIRFLOW - NATURAL VENTILATION

(source: CoM, 2004)

Figure 2: Schematic overview of ventilation system in $\mathrm{CH}_{2}$ toilets 
At night, one of the strategies employed to simultaneously cool the internal fabric of the building in summer and introduce fresh air into the building is night purging. The windows will be automatically opened at night when outside air temperatures are between 19 and $21^{\circ} \mathrm{C}$. The area of open window, found necessary for optimal cooling, is $25 \mathrm{~m}^{2}$ per floor (AEC, 2003). Air entering the building at night will not be filtered.

\section{SYSTEM COMPONENTS}

The ventilation system in the $\mathrm{CH}_{2}$ building comprises a number of components. These are now described and their contribution to the efficacy of the system as a whole is discussed.

\section{Air intakes}

The position and height of the fresh air intake has a direct bearing on the quality of the fresh air introduced into the building. If the air intake is placed in an area of high concentration of polluted air, then it is likely that indoor levels will reflect this, irrespective of the quality of the filtering system. The impact of the location of air intake on a naturally ventilated building located close to a busy urban road was investigated by wind tunnel experiments (Green et al., 2001). The authors found that by locating the intakes on the non-roadside of the building, maximum concentrations of tracer gas were $50 \%$ lower than for roadside locations. They also found that irrespective of wind direction roof-mounted intakes resulted in significantly lower concentrations. Concentrations at the first floor level, however, were only $5 \%$ lower than at the street level.

The analysis of Melbourne's inner city air quality, described earlier, indicates that on some occasions the level of certain pollutants can exceed desirable levels. The fresh air intakes for the $\mathrm{CH}_{2}$ building are located approximately 38 metres above street level and therefore concentrations of all pollutants should be lower than EPA city measurements. However, in the case of the toilets, fresh air enters from the outside via louvres and for the lower storeys of the building potentially this could mean that air with an unacceptable level of pollutants could be admitted to these areas on occasions. Ventilation air intake positions should also be carefully sited with respect to the cooling towers. Although the cooling of the $\mathrm{CH}_{2}$ building is by an indirect system and the cooling tower water flows in a closed loop, drift of droplets from cooling towers may enter the building, particularly when the windows are open. According to NOHSC (1989), drift must be eliminated or at least reduced to $0.02 \%$ of the circulated water.

\section{Wind turbines}

Six wind-assisted extraction vanes or turbines are to be mounted on top of the north façade to assist in drawing stale air out of the office spaces. These units are to be $3.5 \mathrm{~m}$ high and custom designed for the $\mathrm{CH}_{2}$ building. At night when wind conditions are favourable, the turbines will be used to assist the flow of air during night purge operations. At the time of this evaluation, no details of their design or performance were available and therefore a critical assessment is not possible. The concept of improving ventilation efficiency using turbine ventilators, however, is not new. West (2001) reports favourably on the use of the stack effect and wind driven long volume turbines (LVTs) on the Science Precinct Building of the University of New South Wales to assist ventilation, where there is a "good, constant wind source". However, no building performance data was reported for the NSW building.

Some research literature reports the performance of these devices themselves. Lai (2003) discusses the performance of the common turbine ventilator on extraction rates, following wind tunnel experiments. Unfortunately the wind velocity range (10-30 $\left.\mathrm{m} \mathrm{s}^{-1}\right)$ used by that author is not representative of central Melbourne, so the research has limited value. The average long-term wind velocity in Melbourne is in the range of 2.6-3.3 m $\mathrm{s}^{-1}$ (Roy and Miller, 1981). Wind velocity will increase with height according to the 'seventh-root' law and at $40 \mathrm{~m}$ the velocity will be approximately $4 \mathrm{~m} \mathrm{~s}^{-1}$. At the lowest velocity $\left(10 \mathrm{~m} \mathrm{~s}^{-1}\right)$ used by Lai (2003), the induced velocity increased from approximately $60 \mathrm{~m}^{3} \mathrm{~h}^{-1}$ (with no ventilator) to $140 \mathrm{~m}^{3} \mathrm{~h}^{-1}$ for a $0.5 \mathrm{~m}$ diameter turbine ventilator. The total office volume in the $\mathrm{CH}_{2}$ building is approximately $28,000 \mathrm{~m}^{3}$. Using six wind turbines, as proposed, each unit would be required to induce $4667 \mathrm{~m}^{3} \mathrm{~h}^{-1}$ for an air change rate of 1.0. Assuming that the output of the proposed $3.5 \mathrm{~m}$ high turbines is proportional to the $0.5 \mathrm{~m}$ unit, the best achievable ach ${ }^{-1}$ would be 0.2 at a wind speed of $10 \mathrm{~m} \mathrm{~s}^{-1}$.

\section{Air filters}

High efficiency filters are capable of removing $95 \%$ of particles with an aerodynamic diameter of $0.03 \mu \mathrm{m}$ and can reduce the total indoor concentration of particles of this size by a factor of 10 to 15 (Fisk and Rosenfeld, 1997). Filters may be flat or pleated. The former are suitable to collect large particles and can be made of a variety of materials (glass, synthetic or vegetable fibres, or animal hair). Pleated filters use smaller fibres and can collect smaller particles. However, used filters, while removing particles from the passing air, can also pollute that air instead of cleaning it. According to Clausen (2004), a "used filter in a ventilation system can have an adverse impact on perceived air quality, SBS symptoms, and performance of office work". Bluyssen et al. (2003) state that filters are one of the main sources of pollution, particularly odours, in normal ventilation systems. Those authors also concluded from a study of the literature that it was still unclear what causes sensory pollution from filters. One clear finding was that the water content of the filters emerged as a clear factor contributing to microbial growth. A series of experiments on filters by Bluyssen et al. (2003), performed as part of the European AIRLESS project found that:

\section{- low temperature (below $0^{\circ}$ ) and high humidities (>80\%) may produce odour intensities.}

- micro-organisms were not the main pollution sources in filters, as measured by sensory emissions.

- glass fibre filters had less sensory emission than cellulose.

- new filters ( 3 days old) emitted higher odours than 33 day old filters. As filters age, the pollution level increases again.

- there was no statistical difference in odour intensity or VOC emissions between filters subject to continuous or intermittent flow.

- an increase in airflow did not change odour intensity.

All of the air entering the $\mathrm{CH}_{2}$ building is to be passed through primary and secondary filters. This means that the concentrations of many of the particulates of outside origin (see Table 3) introduced into the $\mathrm{CH}_{2}$ displacement ventilation system may be greatly reduced. Precise details of the filtering system to be used in the $\mathrm{CH}_{2}$ building were unavailable at the time of writing this study, so it is not possible to comment on the likely efficacy of the system, but average arrestance rates of $>90 \%$ have been specified.

\section{Ducting}

Ductwork, both new and old, will pollute air passing through it. The cause and extent of the pollution will depend on the manufacturing process, the type of ducting used and the length and design of the system. Concentrations of dust in ductwork will 
provide the conditions for the growth of microorganisms. These concentrations are determined by the quantity of dust in the passing air, which is a function of the filtration system. The velocity of the air will determine the deposition rate and the duct geometry will determine where depositions of dust will accumulate. Dust will adhere to any surface film of oil, if this has been used in the duct manufacturing process. If the water content of the passing air is high, the opportunity for microbial growth is increased. The longer the ductwork, the worse the pollution at the outlet end and smooth ducting will be superior to any spirally wound or flexible varieties.

All of the fresh air entering the $\mathrm{CH}_{2}$ building is drawn down through ducting on the south side of the building and then distributed into the offices via controllable vents. A detailed evaluation of the $\mathrm{CH}_{2}$ ducting system was not possible from the information available at the time of this study. Table 4 of Bluyssen et al. (2003) suggests fifteen strategies to ensure the design and operation of a good ducting system, including using a material that does not use oil in the manufacturing process or emit pollutants, and has a smooth interior surface. Sharp-edged curves, transition pieces or self-tapping screws in walls of ducts should be avoided to prevent condensation points. Flexible ducting should be avoided, if possible, and insulation should be on the outside of any ducting. Finally, contamination of the ducting should be avoided during the construction process.

\section{Building materials, paint, furniture and fittings}

Some aspects of the $\mathrm{CH}_{2}$ building have been addressed specifically to reduce the hazards listed in Table 1. For example, "all materials used in $\mathrm{CH}_{2}$ are being subjected to a full environmental audit to ensure, among other things, that low volatile organic compound materials are used in products such as carpets, paints adhesives and sealants" (CoM, 2004). A comprehensive database, based on replies to an environmental performance questionnaire of material and product suppliers, has been established to guide material selection decisions (Designlnc, 2003). All input data will be audited by the CSIRO and the outcome will be used as the basis for final product selection. At the time of this assessment, no decisions on particular products relevant to this study had been made. Since the building is to be naturally ventilated at night, it is possible that the building fabric and furnishings may act as sinks for incoming pollutants.

\section{Indoor plants to absorb VOCs}

Potted plants will be part of the 'system' used in the $\mathrm{CH}_{2}$ building to reduce contaminants in the indoor air. Research in Australia has demonstrated the ability of certain plants and their potting mix to reduce the concentration of VOCs in enclosed spaces (Wood et al., 2002). In experiments conducted in test chambers, Spathyphyllum wallisi (Petite Peace Lilies) were shown to reduce concentrations of benzene from $25 \mathrm{ppm}$ to almost zero over 2-3 days. Dracaena deremensis (Janet Craig) were also observed to reduce $n$-hexane levels from $100 \mathrm{ppm}$ to approximately 70 and $10 \mathrm{ppm}$ in 2.5 and 11 days respectively. Although the authors did not show the natural decay rate of the two VOCs in test chambers without plants or growing medium, leak tests were conducted to correct for chamber leakage. The VOC removal rate was found to vary with species. For benzene, the highest rate of $686 \mathrm{mg} \mathrm{m}^{-3} \mathrm{~d}^{-1}$ per $\mathrm{m}^{2}$ of leaf area was achieved by the Dracaena deremensis. For $n$-hexane, Howea forteriana (Kentia palm) removed $4032 \mathrm{mg} \mathrm{m}^{-3}$ $\mathrm{d}^{-1}$ per $\mathrm{m}^{2}$ of leaf area, almost double that achieved by the next best performing species, Spathyphyllum wallisi.

The number and type of potted plants proposed for use in the $\mathrm{CH}_{2}$ building had not been decided at the time of this study. The levels of benzene and $n$-hexane used by Wood et al. (2002) were $25 \mathrm{ppm}$ $\left(80 \mathrm{mg} \mathrm{m}^{-3}\right)$ and $100 \mathrm{ppm}\left(353 \mathrm{mg} \mathrm{m}^{-3}\right)$, which were five and two times the Australian maximum allowable occupational exposure concentration (NOHSC, 1995b). $\mathrm{N}$-hexane is an indoor pollution source emanating from furnishings, cleaning agents, cosmetic and clothes. Some of these (furnishing and cleaning agents) can be limited by initial design and on-going management decisions made for $\mathrm{CH}_{2}$. Benzene will mainly come from vehicle emissions and poses a greater hazard because of the building's location and the ingress of unfiltered air at night. Plants with the greatest ability to absorb benzene would therefore be the most appropriate choice.

\section{PERFORMANCE OF NON-AIR CONDITIONED OFFICE BUILDINGS}

The $\mathrm{CH}_{2}$ building uses a mechanically driven ventilation system during the day and a naturally driven system at night. There is no recycling of air (i.e. all ventilation air is outside air). The toiletbathrooms in the building are naturally ventilated at all times. Comparison with office buildings with similar systems is therefore appropriate in terms of air quality, health and productivity.

\section{Air quality}

For an initial perspective on the levels of TVOC concentrations in all types of office building, the work of Brown et al. (1994) is useful. These authors, reviewing 50 overseas studies, found that that the concentrations of total volatile organic compounds (TVOCs) are generally appreciably higher in established residential dwellings compared to office buildings (Table 6). The reasons for this difference were unknown. The concentrations in new and 'complaint' buildings of both types were higher and of similar levels than in established buildings. Although the number of offices is considerably smaller than the number of residential buildings, the data suggests that office workers are more likely to be exposed to more harmful air in their own homes than in their workplace. 


\begin{tabular}{|l|r|r|}
\hline Building Type & No. of Buildings & $\begin{array}{c}\text { TVOC WAGM } \\
\left(\mu \mathrm{g} \mathrm{m}^{-3}\right)\end{array}$ \\
\hline Residential & 1081 & \\
\hline - Established & 33 & 1130 \\
\hline - New & 14 & 4500 \\
\hline - Complaint & & 520 \\
\hline Office & 60 & \\
\hline - Established & 1 & 180 \\
\hline - New & 51 & 4150 \\
\hline - Complaint & & 490 \\
\hline
\end{tabular}

(source: derived from Brown et al., 1994)

Table 6: Comparison of TVOC concentrations in established, new and complaint residential and office buildings

When various studies of buildings specifically using natural ventilation were reviewed, the findings are mixed. For example, Hedge et al. (1989) found no statistical differences in concentrations of carbon dioxide and monoxide, ozone and total oxidants in two office buildings with different ventilation systems. However, concentrations of formaldehyde, VOCs and respirable particulates were higher in the building with the HVAC system.

Three offices in central London and one in a rural location, all naturally ventilated, were evaluated by Phillips et al. (1993). Although the offices of the $\mathrm{CH}_{2}$ building are mechanically ventilated during the day with filtered and conditioned air, the results of the study are indicative of air quality in the toilets during the day and the potential levels of contaminants occurring in the building at night. Carbon dioxide levels exceeded 1000 ppm in all of the monitored offices at some time during the day over the two-month monitoring period. Carbon monoxide levels ranged from 1.9-5.4 ppm, which was $36-76 \%$ of the outdoor level. The lowest value was measured in the rural location. Peak levels corresponded to periods of peak traffic. $\mathrm{NO}_{\mathrm{x}}$ levels followed a similar trend to $\mathrm{CO}$ levels and peak values ranged from $0.11-0.137 \mathrm{ppm}(23-68 \%$ of outdoor level) for the three city offices. Ekberg (1996) confirms these higher values of indoor-outdoor level ratios. For an ach of $1.9 \mathrm{~h}^{-1}$, Ekberg demonstrated that the ratio of indoor peak concentration to outdoor peak concentration can be as high as 0.6 , assuming a triangle concentration pulse, indoor pollution sources and sinks to be zero and no filtration, for a mechanically ventilated building.

\section{Health}

Fisk (2002) refers to a study that found that there was a $35 \%$ reduction in short-term absence in buildings with higher ventilation rates. Another study cited by Fisk (2002) suggested "that a $10 \mathrm{cfm}$ $\left(5 \mid \mathrm{s}^{-1}\right)$ per person increase in ventilation rates would decrease prevalences of the most common SBS symptons by one-third on average." Even higher ventilation rates have been advocated now for good health (Wargocki et al., 2002a). In a review of 105 papers the effects of ventilation on health, comfort and productivity in nonindustrial indoor environments, a multidisciplinary group concluded that outdoor air supply rates below $25 \mathrm{I} \mathrm{s}^{-1}$ per person increase the risk of SBS symptoms and short-term sick leave. The rate proposed for the $\mathrm{CH}_{2}$ building is $22.5 \mathrm{I} \mathrm{s}^{-1}$ per person, which while considerably higher than current Australian building standards requirements, is still $10 \%$ lower than some current thinking in Europe.
Fresh air at whatever rate may be delivered by a mechanical or natural ventilation system. Both of these methods of air delivery are employed in the $\mathrm{CH}_{2}$ building. The findings related to the system of fresh air delivery are mixed. In their comparison between an air conditioned and adjacent naturally ventilated office cited previously, Hedge et al. (1989) found that health impacts were significantly lower in the naturally ventilated office, although no significant correlation could be found between the pollutant concentrations and symptom prevalence. There was some significance with feeling ill and formaldehyde levels. The measurements of the indoor climate in 14 town halls were made in Copenhagen and compared with results of a questionnaire study of over 4000 employees (Skov and Valbjorn, 1987). No statistical difference could be established between the naturally ventilated and mechanically ventilated buildings, although the lowest prevalence of mucosal irritation and work-related general symptoms were found in the oldest town halls. This latter finding appears to support the conclusion of Brown et al. (1994) cited earlier. By contrast, another comparison between an airconditioned and a naturally ventilated building (Parat et al., 1997) found that air microbial content was significantly higher and more variable in the latter building. In addition, the fungal content of naturally ventilated building was strongly dependent on outside levels, while that in the air-conditioned building was relatively constant. No difference could be observed in various gaseous pollutants.

Higher ventilation levels have been associated with reduced sick leave (Milton et al., 2000). These authors analysed the sick leave over one year for some 3700 employees in a large US manufacturer and found consistent associations of increased sick leave with lower levels of outdoor air supply, but the reasons for this were not clear. The authors also found an association between humidification and increased sick leave, which they suggest may be due to the longer survival rate of common respiratory pathogens in a more humid environment.

\section{Productivity}

It should be noted that office productivity is a complex topic and there are many factors which can impact on workplace performance. Ventilation and indoor air quality are only two contributory factors along with temperature, noise, light, stress, morale, workload and management. Isolating the effect of ventilation and air quality alone is therefore difficult. Reviewing the linkages between improved environmental conditions and 
productivity, Fisk and Rosenfield (1997) also caution that much of the research is from laboratory experiments and their relevance to "real-world settings is uncertain". For example, Wargocki et al. (2002b) demonstrated the significance of pollution loads on simulated office work. Some more recent measurements in call centres appears, however, to confirm the link between airflow rate and the productivity of the workers in that type of workplace. Tham (2004) found that increasing the supply of outdoor air at $24.5^{\circ} \mathrm{C}$ from 5 to $10 \mathrm{I} \mathrm{s}^{-1}$ per person decreased the talk time of call-centre workers in a tropical country significantly, compared to a supply temperature of $22.5^{\circ} \mathrm{C}$. The impact on the productivity of 26 northern European call-centre operators of a variable airflow rate, in conjunction with clean and used air filters, was investigated by Wargocki et al. (2004). Replacing a used filter with a clean filter reduced talk-time by about $10 \%$ at the high flow rate but had no significant effect at a lower rate. Talk-time increased by $8 \%$ with a used filter and high flow rate, but decreased by $6 \%$ with a clean filter. These findings are perhaps of significance to the operation of the $\mathrm{CH}_{2}$ building air filter system.

\section{CONCLUSIONS}

Since the building has yet to be completed, commissioned and occupied, conclusions about the effectiveness of the ventilation strategy and its impact on occupant health are necessarily speculative. However, clean fresh air in adequate quantities is clearly required for human health and perceived well being. The daytime fresh air supply for the $\mathrm{CH}_{2}$ offices will be provided by a mechanical system at a rate of $22.5 \mathrm{I} \mathrm{s}^{-1}$ per person, which is slightly lower than currently advocated in Europe but significantly higher than required by current building standards in Australia. In the toilets and at night, however, ventilation of the offices will be induced by natural means. Ventilation of the offices at night is mainly required for cooling, rather than the removal of pollutants and ventilation effectiveness at night may not influence air quality during the daytime. However, removal of odours and particulates from the incoming air in the toilets, especially those near ground level, may be inadequate if natural ventilation alone is used.

High levels of ventilation are now often advocated to improve indoor air quality, health and productivity. However, a survey of 56 HVAC office buildings in nine countries all over Europe found that although there was an average ventilation rate of $25 \mathrm{I} \mathrm{s}^{-1}$ per person, nearly $30 \%$ of occupants and $50 \%$ of visitors still found the air unacceptable (Bluyssen et al. 1996). High ventilation rates alone are therefore no guarantee of acceptable indoor air quality. The same study concluded that the materials, furnishings and activities in the office and the ventilation system itself were the important sources of air pollution, not the occupants. The measures taken to reduce the internal sources of pollution in $\mathrm{CH}_{2}$ such as low emission fittings and the use of plants to absorb pollutants should be effective and therefore the major source of pollutants will be external. Given its inner city location and the possibility of excess particulate levels, the efficacy of the filtering system will therefore be a major determinant in indoor air quality.

Evidence for reduced sickness due to higher ventilation rates does not appear to be conclusive. In the study of over 6500 office workers, Bluyssen et al. (1996) could not establish a correlation between the occupants' health and their acceptability of the air quality, although there was a significant correlation between perceptions of air quality and measured ventilation rates. In terms of a direct link between ventilation and productivity, the evidence is to date mainly from experiments, rather than measured data from real-life conditions. Some measured productivity gains amongst call-centre workers have been linked to airflow rate, but not necessarily at high levels. The effect of ventilation rate on performance is therefore not independent of other factors such as temperature and filter system condition. Productivity increases will be achieved indirectly if there is less sickness-related absence. The current evidence suggests this is likely to be the major benefit of the ventilation system proposed for the $\mathrm{CH}_{2}$ building.

\section{REFERENCES}

AEC (2003), Aircond Design Strategy, Advanced Environmental Concepts Pty Ltd, North Sydney, NSW.

ASHRAE (2001), Fundamentals Handbook (SI), American Society of Heating, Refrigeration and Airconditioning Engineers, Atlanta.

Bluyssen, P.M., de Oliveira Fernandes, E., Groes, L., Clausen, G.H., Fanger, P.O., Valbjorn, O., Bernard, C.A. and Roulet, C.A. (1996), 'European indoor air quality audit project to optimize indoor air quality and energy consumption in office buildings', Indoor Air Journal, vol.6, pp.221-338.

Bluyssen, P.M., Cox, C., Seppanen, O., de Oliveira Fernandes, E., Clausen, G., Muller, B. and Roulet, C.A. (2003), 'Why, when and how do HVAC-systems pollute the indoor environment and what to do about it? The European AIRLESS project', Building and Environment, vol.38, pp.209-225.

Brown, S.K., Sim, M.R., Abramson, M.J. and Gray, C.N. (1994), 'Concentrations of volatile organic compounds in indoor air - a review', Indoor Air, vol.4 pp.123-134.

CoM (2004), City of Melbourne website, http://www.melbourne. vic. gov.au/info. cfm?top=171\&pa=1943\&pg=1934 (access 14 July 2004).

Clausen, G. (2004), 'Ventilation filters and indoor air quality: a review of research from the International Centre for Indoor Environment and Energy', Indoor Air, vol.14, pp.202-207.

Designinc (2003), Eco Report - Material + Product Selection, Designinc Melbourne Pty Ltd, Melbourne.

Ekberg, L.E. (1996), 'Relationships between indoor and outdoor contaminants in mechanically ventilated buildings', Indoor Air, vol.6, pp.41-47.

EPA (2000), Effects of ambient air pollution on daily mortality in Melbourne 1991-1996, Melbourne mortality study, Environment Protection Authority, Southbank, Melbourne.

EPA (2001), Ambient air quality NEPM monitoring plan - Victoria, Environment Protection Authority, Southbank, Melbourne, February.

EPA (2004a), Victoria's air quality 2003. Air monitoring data tables, Environment Protection Authority, Southbank, Melbourne.

EPA (2004b), Victoria's air quality 2003. Environment Report, Environment Protection Authority, Southbank, Melbourne.

Fisk, W.J. (2002), 'How IEQ affects health, productivity', ASHRAE Journal, May, pp.56-58.

Fisk, W.J. and Rosenfeld, A.H. (1997), 'Estimates of improved productivity and health from better indoor environments', Indoor Air, vol.7, pp.158-172. 
Green, N.E., Etheridge, D.W. and Riffat, S.B. (2001), 'Location of air intakes to avoid contamination of indoor air: a wind tunnel investigation', Building and Environment, vol.36, pp.1-14.

Hedge, A., Sterling, T.D., Sterling, E.M., Collett, C.W., Sterling, D.A. and Nie, V. (1989), 'Indoor air quality and health in two office buildings with different ventilation systems', Environment International, vol.15, pp.115-128.

Lai, C. (2003), 'Experiments on the ventilation efficiency of turbine ventilators used for building and factory ventilation', Energy and Buildings, vol.35, no.9, pp.927-932.

Milton, D.K, Glencross, P.M. and Walters, M.D. (2000), 'Risk of sick leave associated with outdoor air supply rate, humidification and occupant complaints', Indoor Air, vol.10, pp.212-221.

NOHSC (1989), Legionnaire's Disease and Related IIInesses, National Occupational Health and Safety Commission, Australian Government, Canberra.

NOHSC (1995a), Guidance Note on the Interpretation of Exposure Standards for Atmospheric Contaminants in the Occupational Environment, [NOSHC:3008 (1995)], 3rd. edition, National Occupational Health and Safety Commission, Australian Government, Canberra.

NOHSC (1995b), Exposure Standards for Atmospheric Contaminants in the Occupational Environment, National exposure standards database, National Occupational Health and Safety Commission, Australian Government, Canberra.

Olesen, B.W. (2004), 'International standards for the indoor environment', Indoor Air, vol.14, suppl.7, pp.18-26.

Owen, M.K., Ensor, D.S. and Sparks, L.E. 1992, 'Airborne particle sizes and sources found in indoor air', Atmospheric Environment, part A, general topics, vol.26, no.12, pp.2149-62.

Phillips, J.L., Field, R., Goldstone, M., Reynolds, G.L., Lester, J.N. and Perry, R. (1993), 'Relationships between indoor and outdoor air quality in four naturally ventilated offices in the United Kingdom', Atmospheric Environment, vol.27A, no.11, pp.1743-1753.

Parat, S., Perdix, A., Fricker-Hidalgo, H., Saude, I., Grillot, R. and Baconnier, P. (1997), 'Multivariate analysis comparing microbial air content of an air-conditioned building and a naturally ventilated building over one year', Atmospheric Environment, vol.31, no.3, pp.441-449.

Roy, G.G. and Miller, S.G. (1981), Data Handbook for Australian Solar Energy Designers, Research Report No. 7, School of Architecture, University of Western Australia.

Skov, P., and Valbjorn, O. (1987), 'The "sick" building syndrome in the office environment: the Danish town hall study', Environment International, no.13, pp.339-349.

Tham, K.W. (2004), 'Effects of temperature and outdoor air supply rate on the performance of call center operators in the tropics', Indoor Air, vol.14, suppl.7, pp.119-125.

Wargocki, P., Sundell, J., Bischof, W., Brundrett, G., Fanger, P.O., Gyntelberg, F., Hanssen, S.O., Harrison, P., Pickering, A., Seppanen, O. and Wouters, P. (2002a), 'Ventilation and health requirements in non-industrial indoor environments: report from a European Multidisciplinary Scientific Consensus Meeting (EUROVEN)', Indoor Air, vol.12, pp.113-128.
Wargocki, P., Lagercrantz, L., Witterseh, T., Sundell, J.,Wyon, D.P. and Fanger, P.O. (2002b), 'Subjective perceptions, symptom intensity and performance: a comparision of two independent studies, both changing similarly the pollution load in an office', Indoor Air, vol.12, pp.74-80.

Wargocki, P., Wyon, D.P. and Fanger, P.O. (2004), 'The performance and subjective responses of call-center operators with new and used supply air filters at two outdoor air supply rates', Indoor Air, vol.14, suppl.8, pp.7-16.

West, S. (2001), 'Improving the sustainable development of building stock by the implementation of energy efficient, climate control technologies', Building and Environment, vol.36, pp.281289.

WHO (2000), Air Quality Guidelines, 2nd. edition, World Health Organisation Regional Office for Europe, Copenhagen, Denmark.

Wood, R.A, Orwell, R.L., Tarran, J., Torpy, F., and Burchett, M. (2002), 'Pot-plants really do clean indoor air. Potted-plant/growth media interactions and capacities for removal of volatiles from indoor air', Journal of Horticultural Science and Biotechnology, vol.77, pp.120-129. 


\section{CITY OF MELBOURNE RESPONSE}

Reading a detailed analysis of air quality can be a bit like reading fine print on the potential side-effects of standard prescription medicine - without a strong sense of perspective it can sound alarming, even when the chances of any such effects are remote in the extreme. Aye and Fuller, in their paper on $\mathrm{CH}_{2}$ 's proposed ventilation system, raise a series of points that similarly must be read in context and with perspective.

For instance, Aye and Fuller make repeated references to the quality of outdoor air entering the $\mathrm{CH}_{2}$ toilets and the potential for undesirable odour. They say outside air may on occasion exceed targets for PM10 particles and that during 2003, potentially at the time of bushfires and dust-storms, they exceeded the 2008 goal for ozone and particulates.

While this may be the case, the perspective must be applied that more than 600,000 people in the City of Melbourne every week day breathe this very same air - some of them all day long - and that staff are unlikely to linger for extended periods in the office toilets. Furthermore, the same air has been used to naturally ventilate the City of Melbourne's Commonwealth Bank Building offices for many years, with no particular history of odour complaints. The $\mathrm{CH}_{2}$ toilets closest to ground level, which the authors are most wary of, will be mechanically rather than naturally ventilated. People enjoying just one cup of coffee at any of the city's plethora of outdoor cafes can expect to inhale a great many more pollutants than they are likely to encounter in regular visits to a $\mathrm{CH}_{2}$ bathroom.

Aye and Fuller acknowledge their paper is based on readings taken from an air quality monitoring station 19 metres above ground (rather than $\mathrm{CH}_{2}$ 's desirable 38 metres) and 750 metres away. However it is important to understand this station is about seven city blocks distant in an area much closer to wide busy roads than the narrow and often closed-off streets surrounding $\mathrm{CH}_{2}$. The nearest main road to $\mathrm{CH}_{2}$ is Bourke Street, which in very recent times has been substantially and permanently closed to all but tram traffic in the vicinity of $\mathrm{CH}_{2}$. To reintroduce significantly more traffic to Swanston St, as alluded to by the authors, is a very long bow to draw. It would require the removal of millions of dollars in street infrastructure, the reversal of long-held Council policy and the risking of a renaissance in pedestrian and retail activity in the street, as measured in 10 years of award-winning research.

In regards to the quality of the building's air filters, the City of Melbourne has a rigorous maintenance program for all its buildings that is well within the Australian standards - and this most certainly extends to regularly measuring indoor air quality and routinely cleaning and replacing air filters.

Aye and Fuller draw on two studies - one in 1987 and one in 1997 - to question whether naturally ventilated or mechanically ventilated buildings are preferable. Apart from the fact this begs the question why there are not a great many more studies on the subject, it also should be read in context. Apart from the toilets, $\mathrm{CH}_{2}$ is not and never was intended to be a naturally ventilated building. It will be ventilated by filtered air, with outdoor air being used only on cool nights when the building is empty and as an energy saving technique only.

Further clarification is also required for the authors' reference to higher ventilation rates in $\mathrm{CH}_{2}$ being considerably higher than Australian standards but below some current thinking in Europe. Certainly the $\mathrm{CH}_{2}$ design team believes the higher-than-standard ventilation rates will help staff be more effective at work, but it expects the system to provide far greater benefits by minimizing air mixing between occupants working in the same area. This means workers will be much less exposed to the seasonal colds and flu passed by the mixed air common to most other Australian office buildings. It is through this and a plethora of other factors - certainly not ventilation rates alone - the designers expect to reduce sickness in the workplace.

In relation to productivity, the authors make a point with which there can be little disagreement. Temperature, noise, light, stress, morale, workload and management all have a part to play alongside ventilation and indoor air quality on the satisfaction and productivity of workers. To that, the $\mathrm{CH}_{2}$ design team would add a plethora of other factors: the materials used, office layout, aesthetics, the ability to contribute and workplace values are just a few.

Ultimately, $\mathrm{CH}_{2}$ was designed to reflect the planet's ecology, which is an immensely complex system of interrelated components. Just as it is impossible to completely assess the role of any part of this ecology without reference to the whole, $\mathrm{CH}_{2}$ comprises many parts that work together to create a harmonious environment. Context and perspective must be applied at every step of the way. 